\title{
Modes of Action of the New Arylguanidine Abafungin beyond Interference with Ergosterol Biosynthesis and in vitro Activity against Medically Important Fungi
}

\author{
C. Borelli ${ }^{a} \quad$ M. Schaller ${ }^{b} \quad$ M. Niewerth ${ }^{a} \quad$ K. Nocker ${ }^{c} \quad$ B. Baasner ${ }^{d} \quad$ D. Berg ${ }^{e}$ \\ R. Tiemann ${ }^{\text {e }}$ K. Tietjen ${ }^{\text {e }}$ B. Fugmann ${ }^{d}$ S. Lang-Fugmann ${ }^{d}$ H.C. Korting ${ }^{\text {a }}$ \\ ${ }^{a}$ Department of Dermatology and Allergology, Ludwig Maximilians University, Munich, ${ }^{b}$ Department of \\ Dermatology, Eberhard Karls University, Tübingen; 'York Pharma AG, Homberg, dBaFuS GmbH, Ratingen, \\ and ${ }^{\mathrm{e}}$ Research Fungicides Biology Fungicides, Bayer Crop Science AG, Monheim, Germany
}

\section{Key Words}

Abafungin - Antifungal agents - Arylguanidines - Azoles •

Cell membrane $\cdot$ Ergosterol biosynthesis

\begin{abstract}
Background: In contrast to the increasing numbers of agents for the treatment of invasive fungal infections, discoveries of new antifungal agents with therapeutic value in dermatomycoses are reported only rarely. Methods: Abafungin (chemical abstracts service registry No. 129639-79/8) is the first member of a novel class of synthetic antifungal compounds, the arylguanidines. It was first synthesized at Bayer AG, Leverkusen, Germany, and its antifungal action was discovered during the screening of $\mathrm{H}_{2}$-receptor antagonists based on the structure of famotidine. To obtain insight into its mode of action and antifungal activity, various tests were carried out with different fungal pathogens in vitro. $\boldsymbol{R e}$ sults: Abafungin was found to have potent antifungal activity. Furthermore, mode-of-action studies suggested that abafungin exerts its antifungal activity regardless of whether the pathogens are growing or in a resting state. One target of abafungin was found to be the inhibition of transmethylation at the C-24 position of the sterol side chain, catalyzed
\end{abstract}

by the enzyme sterol-C-24-methyltransferase. A second action of abafungin seems to be a direct effect on the fungal cell membrane. Conclusion: The observed characteristics of abafungin indicate that abafungin might be a promising antifungal agent defining a new class of antimycotics.

Copyright $\odot 2008$ S. Karger AG, Basel

\section{Introduction}

In the past decades, fungal infections have increased, especially in immuno-compromised patients [1-4]. The currently used antifungal drugs belong to ten different major groups of substances [5]. These are the allylamines, benzofurans, echinocandins, hydroxypyridones, imidazoles, morpholines, polyenes, pyrimidines, thiocarbamates and triazoles [6-11]. The target of many of these antifungal drugs is ergosterol biosynthesis. Ergosterol is one of the key components of the fungal cell membrane. As the main sterol of yeasts and other fungi, it is necessary for the growth of cells and normal membrane function. It serves as a bioregulator of membrane fluidity, asymmetry and membrane integrity and contributes to the proper function of membrane-bound enzymes [12].

\section{KARGER}

Fax +41613061234 E-Mail karger@karger.ch www.karger.com (c) 2008 S. Karger AG, Basel

$0009-3157 / 08 / 0544-0245 \$ 24.50 / 0$

Accessible online at:

www.karger.com/che
Dr. Claudia Borelli

Department of Dermatology and Allergology, Ludwig Maximilian University

Frauenlobstrasse 9-11, D-80337 Munich (Germany)

Tel. +49 895160 6151, Fax +49 8951606153

E-Mail claudia.borelli@med.uni-muenchen.de 
Over the past 20 years, interference with the ergosterol biosynthesis pathway of fungi has been a major aim of antifungal drug research and development. Other targets are directly related to the cell membrane, the synthesis of amino acids or the cell wall.

Terbinafine is the major drug from the class of the allylamines. It exhibits a primarily fungicidal mode of action. It attacks a broad range of dermatophytes and molds but shows lower activity against yeasts [13]. Terbinafine acts on fungal ergosterol biosynthesis by specific and selective inhibition of fungal squalene epoxidase. This leads to intracellular accumulation of squalene and prevents the synthesis of lanosterol. Its affinity to cytochrome $\mathrm{P}_{450}$ is lower than that of azoles. Consequently, terbinafine shows lower interaction in co-medication in comparison to the azoles.

The benzofuran griseofulvin is one of the oldest systemically administered antifungal drugs and has been used since 1959. Griseofulvin is synthesized by Penicillium griseofulvum and other Penicillium species. Its activity is limited to dermatophytes. It interacts with microtubuli and inhibits fungal cell mitosis. In hyphae of dermatophytes, griseofulvin causes the characteristic 'curling effect'. Even using ultramicrosize griseofulvin, which is better absorbed, cure rates for toenail onychomycoses are $<40 \%$ despite treatment over 1 year or longer [14].

Caspofungin influences the fungal cell wall by interference with the synthesis of $\beta-(1,3)$-D-glucan $[6,15]$. It acts fungicidally on yeasts and fungistatically on Aspergillus spp.

The azoles are antifungal compounds with five-membered rings, which contain either two (imidazoles) or three (triazoles) nitrogen atoms. Major imidazoles are clotrimazole, miconazole and ketoconazole. Major triazoles are itraconazole, fluconazole and voriconazole. The main target of azoles is the fungal cell membrane. Inhibition of the cytochrome $\mathrm{P}_{450} 3 \mathrm{~A}$-dependent lanosterol 14 - $\alpha$-demethylase leads to accumulation of $14-\alpha$ methylsterol and depletion of ergosterol [16]. Additionally, azoles can inhibit some enzymes of the fungal respiratory chain $[17,18]$.

Ciclopirox olamine and piroctone olamine are topical antifungals belonging to the class of hydroxypyridones. Their mode of action is not well understood [19]. Previous studies have reported that these drugs bind irreversibly to intracellular compounds and act fungicidally by interaction with iron metabolism, metabolic activity and oxygen accessibility [20,21].

Amorolfine is the major drug from the class of morpholines. It interacts with at least two enzymes of the ergosterol biosynthetic pathway, $\Delta^{14}$-reductase and the $\Delta^{7-8}$-isomerase, leading to inhibition of ergosterol biosynthesis at different levels $[22,23]$.

Amphotericin B and nystatin, which belong to the polyene antimycotics, primarily build complexes with ergosterol. This results in disorganization of the fungal cell membrane and formation of specific pores composed of small aggregates of the polyene drugs. Increased membrane permeability leads to depolarization and loss of proteins, nucleotides and other compounds [24]. Amphotericin B also binds unspecifically to other sterols, e.g. cholesterol, which accounts for much of its toxicity.

The halogenated pyrimidine 5-flucytosine is an antimetabolite of cytosine. It is selectively taken up by a cytosine permease. Intracellularly, it is deaminated to 5 -fluorouracil (5-FU). 5-FU is phosphorylated and incorporated into RNA, where it causes miscoding. Additionally, 5 -FU is converted to its deoxynucleoside, which inhibits thymidylate synthetase and thereby DNA synthesis [25]. Because of a fast generation of resistance it is not used for monotherapy.

Thiocarbamates, such as tolnaftate, as well as the allylamines, work by direct inhibition of microsomal squalene epoxidase in ergosterol biosynthesis, which leads to an accumulation of squalene [26].

Unfortunately, resistance to older antifungal drugs has gained more and more importance in the past years [2729]. Therefore, new antifungal agents are still needed, in particular active compounds which might not cause development of resistance very rapidly. However, the development of resistance is more probable, if an antifungal agent inhibits only one essential function of the pathogen, e.g. fungal reproduction or membrane synthesis [28]. In particular, new antifungals targeting several functions of the fungus simultaneously are urgently needed.

We report now on the in vitro data of a new promising substance, which will probably be introduced into antifungal therapy in the near future. Abafungin, chemical abstracts service (CAS) registry No. 129639-79-8CAS, was synthesized at Bayer AG, Leverkusen, Germany, quite some time ago. It was detected while Bayer performed screening tests looking for $\mathrm{H}_{2}$-receptor antagonists, using famotidine as lead structure (fig. 1a). Abafungin is a compound belonging to a new class of microbiocidal arylguanidines. Its chemical structure differs from existing antifungals, including azoles (fig. 1b). We describe tests with abafungin which were performed in the 1990s primarily to study the effects on fungi and to understand its potential mode of action. The reason to report on these data now is that abafungin-based antimy- 
Fig. 1. Chemical structure of famotidine (a) and abafungin (b).

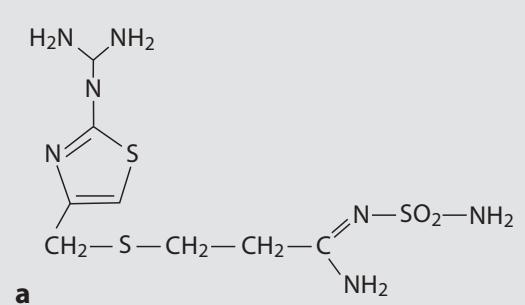

a

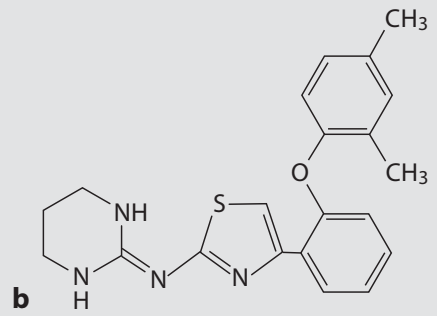

cotics might reach clinical medicine in the near future. Thus, the results of the investigations are considered relevant, although currently preferred approaches were not always chosen in terms of methodology.

\section{Materials and Methods}

\section{Test Media}

The sensitivity of resting fungi was determined in physiological saline or in demineralized water. The nutrient media yeast nitrogen base (YNB; Difco Laboratories, Detroit, Mich., USA), Kimmig and Sabouraud dextrose are standard media for fungi. Kimmig broth, Sabouraud dextrose, T3 medium and additional standard media were all from Difco.

YMM is a hypotonic minimal medium for yeast-like fungi. The composition of YMM is as follows:

\begin{tabular}{ll}
\hline Ingredients & Concentration, g/l \\
\hline Glucose & 10 \\
$\left(\mathrm{NH}_{4}\right)_{2} \mathrm{SO}_{4}$ & 2 \\
$\mathrm{KH}_{2} \mathrm{PO}_{4}$ & 1 \\
$\mathrm{MgSO}_{4} \cdot 7 \mathrm{H}_{2} \mathrm{O}$ & 0.3 \\
$\mathrm{CaCl}_{2}$ & 0.03 \\
L-Asparagine & 2 \\
\hline
\end{tabular}

The composition of $\mathrm{T} 3$ medium is as follows:

\begin{tabular}{ll}
\hline Ingredients & Concentration, g/l \\
\hline Glucose & 10 \\
$\left(\mathrm{NH}_{4}\right)_{2} \mathrm{SO}_{4}$ & 3 \\
$\mathrm{KH}_{2} \mathrm{PO}_{4}$ & 2 \\
$\mathrm{Citric}$ acid & 2 \\
$\mathrm{~K}_{2} \mathrm{CO}_{3}$ & 2 \\
$\mathrm{MgSO}_{4}$ & 0.7 \\
$\mathrm{NaCl}$ & 0.5 \\
Difco yeast extract & 2.5 \\
Pyridoxal hydrochloride & 0.0001 \\
\hline
\end{tabular}

For testing of fungi, the $\mathrm{pH}$ was adjusted with $\mathrm{HCl}$ to 5.0.

\section{Test Organisms}

Test organisms comprised strains of fungi of differing species, most of them medically important. Representatives of yeast-like fungi included in particular Candida albicans. Moreover, dermatophytes were included. The test organisms consisted exclusively of clinical isolates. The isolates had been kept on agar slants and passaged several times before the start of the study. Microbial suspensions were prepared and checked photometrically from freshly grown cultures in physiological saline.

Two isolates of C. albicans were in particular employed in this study, strain TIMM 0144 from the Teikyo University collection and C. albicans $\mathrm{H} 12$ from Bayer's culture collection. Both isolates were maintained by periodic transfer on Sabouraud dextrose agar. The culture of strain TIMM 0144 was initiated by transfer to peptone yeast extract glucose broth overnight at $37^{\circ} \mathrm{C}$. Strain $\mathrm{H} 12$ was initiated in fresh Sabouraud's slant cultures overnight at $28^{\circ} \mathrm{C}$.

\section{Comparative Determination of Minimum Inhibitory \\ Concentrations}

Comparative determination of minimum inhibitory concentrations (MICs) was performed using a broth dilution assay either on the $5-\mathrm{ml}$ scale (dermatophytes and molds) or on the microliter scale (yeasts) and with the agar (agarose) dilution assay. MICs were determined using Kimmig's and T3 media for dermatophytes, and YNB glucose and T3 medium for yeast-like fungi. T3 medium was also used for molds. The MIC was defined as $100 \%$ inhibition of detectable growth after the indicated incubation time. Minimum fungicidal concentrations (MFCs) were determined in the first step, as described for MICs. After the indicated incubation time, diluted and undiluted samples were plated on drug-free agar plates and incubated for 14 days before colony-forming units (CFU) per milliliter were determined. The MFC was defined as the minimal drug concentration which reduced the CFU of the fungal inoculum by two to three orders of magnitude.

\section{Conductivity Measurement}

A fresh overnight culture of C. albicans (strain H12), grown in a slant culture at $28^{\circ} \mathrm{C}$, was washed three times in distilled water and resuspended in distilled water to obtain a density of $6 \times 10^{8}$ $\mathrm{CFU} / \mathrm{ml}$. Abafungin was preincubated for $30 \mathrm{~min}$ at $37^{\circ} \mathrm{C}$ in a water shaker. The conductivity of a cell suspension was measured with a standard electrode KLE 1/T (WTW, WissenschaftlichTechnische Werkstätten, Weilheim, Germany) connected to a conductivity meter LF91 (WTW) before and after adding the cells at a final density of $6 \times 10^{5} \mathrm{CFU} / \mathrm{ml}$. 


\section{Determination of Potassium}

Freshly grown yeast cells of C. albicans were adjusted to a density of $10^{8}$ cells $/ \mathrm{ml}$ in distilled water and placed on a shaker at $37^{\circ} \mathrm{C}$.

After addition of abafungin, samples were taken at the indicated time points and filtered through a glass fiber filter (GF/C, Whatman, Dassel, Germany). Potassium content of the extracellular fluid was determined by colorimetric analysis based on flame spectrochemical analysis (model 775; Hitachi, Tokyo, Japan). The released amounts of $\mathrm{K}^{+}$were expressed as a ratio of the total amount which was obtained from control cells boiled for 10 min in trichloroacetic acid.

\section{Adenosine Triphosphate Assay}

C. albicans cells grown overnight in a slant culture were washed with distilled water or saline (physiological saline solution), resuspended in distilled water or YMM at the final density indicated in the experiments before abafungin was added at a final concentration of $30 \mathrm{mg} / \mathrm{l}$. Measurements of extracellular adenosine triphosphate (ATP) were performed in a bioluminescent assay with Lumit (luciferin and luciferase) [30]. Light emission was determined for $10 \mathrm{~s}$ in $100 \mu \mathrm{l}$ culture samples mixed with $100 \mu$ l of the reagent in a Biocounter M 2500 (Perstorp Analytical; Lumac, Landgraaf, The Netherlands). To measure total ATP, 100 $\mu l$ samples were mixed with $100 \mu$ l of NRB (Nucleotide Releasing Reagent; Perstorp Analytic) to induce cell lysis. After 10 s, $100 \mu \mathrm{l}$ of Lumit were added and light intensity was measured concurrently.

\section{UV Difference Spectroscopic Measurements}

Difference spectra were recorded as described by Epand et al. [31]. All phospholipids and sterols were purchased from Sigma (Sigma-Aldrich, Munich, Germany). Abafungin, phospholipid (phosphatidylcholine, phosphatidylethanolamine, phosphatidylinositol, phosphatidylserine and cardiolipin) and sterol (sitosterol, cholesterol and ergosterol) were dissolved in ethanol to obtain a final concentration of $10^{-4} \mathrm{M}$; abafungin and phosphatidylserine were also diluted to obtain $5 \times 10^{-5} \mathrm{M}$. The sample cuvette was then shaken and allowed to stand for $1 \mathrm{~min}$ at $22^{\circ} \mathrm{C}$. Difference spectral measurements were made in matched tandem cuvettes at room temperature $\left(22^{\circ} \mathrm{C}\right)$ with an Uvicon 820 spectrophotometer (Kontron, Eching, Germany) at wavelengths ranging from 190 to $350 \mathrm{~nm}$.

\section{Measurement of Ergosterol Biosynthesis by Incorporation of \\ ${ }^{14} \mathrm{C}$-Acetate}

Cells of strain TIMM 0144 were adjusted to $10^{7}$ cells $/ \mathrm{ml}$ in the YNB broth. The suspension was incubated at $37^{\circ} \mathrm{C}$ on a shaker with the indicated concentration of abafungin before addition of $7.4 \mathrm{kBq} / \mathrm{ml}^{14} \mathrm{C}$-acetate (NEN Research, Boston, Mass., USA). Test samples were taken after $3 \mathrm{~h}$ of incubation and saponified at $85^{\circ} \mathrm{C}$ for $2 \mathrm{~h}$ in a mixture of $15 \% \mathrm{KOH}, 50 \%$ ethanol and a small amount of pyragol. The lipid fraction was extracted with petroleum ether and evaporated to dryness before dissolving in ether. The sterol was analyzed by thin-layer chromatography. The operation conditions were as follows: for adsorption, $\mathrm{AgNO}_{3}$ silica gel plates were prepared by addition of $10 \%$ silver nitrate to silica gel (60C, Merck, Darmstadt, Germany). The plates were developed with nhexane/isopropylether/ethyl acetate. Radioactivity was measured and calculated using a Bio-image analyzer (BAS 2000; Fuji Film,
Düsseldorf, Germany). Non-radioactive ergosterol was simultaneously developed on $\mathrm{AgNO}_{3}$ silica gel plates and served as a marker.

\section{Measurement of Ergosterol Biosynthesis by}

Gas Chromatography-Mass Spectroscopy

C. albicans cells (strain TIMM 0144), $10^{5}$ cells/ml in YNB broth, were incubated with shaking for $24 \mathrm{~h}$ at $37^{\circ} \mathrm{C}$ in the presence of $1 \mu \mathrm{g} / \mathrm{ml}$ of abafungin. Test samples were taken, saponified and extracted, dissolved in acetone and analyzed by gas chromatography-mass spectroscopy (QP-1000A; Shimadzu, Kyoto, Japan). The operation conditions were as follows: glass column: DB5; carrier gas: helium, and column temperature: $280^{\circ} \mathrm{C}$.

Measurement of Ergosterol Biosynthesis by Incorporation of L-[Methyl $-{ }^{14}$ C]Methionine

Test samples were incubated with different concentrations of abafungin or sinefungin (S-adenosyl-L-methionine analog from Bayer), as comparative inhibitor, with $7.4 \mathrm{kBq} / \mathrm{ml} \mathrm{L}-\left[\right.$ Methyl $-{ }^{14} \mathrm{C}$ ] methionine $(0.2 \mu \mathrm{Ci} / \mathrm{ml}, \mathrm{NEN}$ Research $)$ for $3 \mathrm{~h}$ at $37^{\circ} \mathrm{C}$ in a shaker. The non-saponified lipid fractions were extracted and dissolved in diethyl ether. The sterols were analyzed by thin-layer chromatography. Silica gel plates (F254, Merck) were developed with n-heptane/isopropyl ether/acetate. Radioactivity was measured and calculated using a Bio-image analyzer (BAS2000, Fuji Film).

\section{Results}

\section{Antifungal Spectrum and Inhibitory Activity \\ MICs for Fungi}

Abafungin showed broad activity against pathogenic fungi. The inhibitory activities against dermatophytes (Trichophyton spp., Microsporum spp. and Epidermophyton) were somewhat inferior to those of clotrimazole and terbinafine, but comparable to that of amorolfine und superior to the ones of bifonazole. It showed better antifungal activity than all used standard compounds against the yeast Candida and the mold Aspergillus (table 1). Abafungin reduced the growth rate of $C$. albicans to 30 and $10 \%$ at 0.1 and $1 \mu \mathrm{g} / \mathrm{ml}$, respectively, after a 24 -hour incubation.

\section{MFCs for Fungi}

Abafungin showed broad fungicidal activity against various species of pathogenic fungi (table 2). The MFCs of abafungin with dermatophytes were slightly inferior to those with terbinafine but superior to those with all other comparator drugs. The fungicidal activity of abafungin against yeast-like fungi and molds was clearly superior to that of all other used reference drugs. A complete inhibition of C. albicans was observed with $10 \mu \mathrm{g} / \mathrm{ml}$ after a 48-hour incubation. 
Table 1. Antimicrobial activity of abafungin and comparator drugs against various pathogenic fungi (broth dilution assay)

\begin{tabular}{|c|c|c|c|c|c|c|}
\hline \multirow[t]{2}{*}{ Organisms } & \multirow{2}{*}{$\begin{array}{l}\text { Strains } \\
\mathrm{n}\end{array}$} & \multicolumn{5}{|c|}{ MIC range, $\mu \mathrm{g} / \mathrm{ml}$} \\
\hline & & abafungin & bifonazole & clotrimazole & terbinafine & amorolfine \\
\hline \multicolumn{7}{|l|}{ Dermatophytes } \\
\hline Trichophyton mentagrophytes & 5 & $\leq 0.06-0.5$ & 1 to $>64$ & $\leq 0.06-1$ & $\leq 0.06$ & $\leq 0.06-0.13$ \\
\hline Trichophyton rubrum & 5 & $\leq 0.06-0.25$ & $4-8$ & $\leq 0.06$ & $\leq 0.06$ & $\leq 0.06-0.5$ \\
\hline Trichophyton equinum & 2 & $0.13-0.5$ & $1-4$ & $\leq 0.06$ & $\leq 0.06$ & $\leq 0.06$ \\
\hline Trichophyton tonsurans & 4 & $\leq 0.06-0.25$ & $1-2$ & $\leq 0.06$ & $\leq 0.06$ & $\leq 0.06-4$ \\
\hline Trichophyton ajelloi & 1 & $\leq 0.06$ & 1 & $\leq 0.06$ & $\leq 0.06$ & 0.5 \\
\hline Trichophyton gallinae & 1 & 1 & 1 & $\leq 0.06$ & $\leq 0.06$ & 2 \\
\hline Trichophyton schoenleinii & 1 & $\leq 0.06$ & 1 & $\leq 0.06$ & $\leq 0.06$ & 0.5 \\
\hline Trichophyton verrucosum & 2 & 0.13 & 4 & $\leq 0.06$ & $\leq 0.06$ & $\leq 0.06$ \\
\hline Trichophyton violaceum & 1 & 0.5 & $>64$ & $\leq 0.06$ & $\leq 0.06$ & 0.5 \\
\hline Epidermophyton floccosum & 1 & 0.25 & 1 & $\leq 0.06$ & $\leq 0.06$ & 0.13 \\
\hline Microsporum canis & 4 & $\leq 0.06-1$ & $1-32$ & $\leq 0.06$ & $\leq 0.06$ & $0.5-1$ \\
\hline Microsporum gypseum & 2 & $\leq 0.06-2$ & 16 & $\leq 0.06$ & $\leq 0.06$ & $\leq 0.06$ \\
\hline Clinical isolates, not characterized & 14 & $\leq 0.06-2$ & $1-8$ & $\leq 0.06-1$ & $\leq 0.06$ & $\leq 0.06$ \\
\hline \multicolumn{7}{|l|}{ Yeast } \\
\hline Candida albicans & 8 & $0.5-16$ & 8 to $>64$ & $2-32$ & 16 to $>64$ & 2 to $>64$ \\
\hline Candida glabrata & 8 & $0.5-16$ & 32 to $>64$ & $1-32$ & 8 to $>64$ & 1 to $>64$ \\
\hline Candida guilliermondii & 5 & $0.5-16$ & $>64$ & 1 to $>64$ & 64 to $>64$ & 1 to $>64$ \\
\hline Candida krusei & 5 & $0.5-4$ & $>64$ & $1-2$ & 64 to $>64$ & $1-4$ \\
\hline Candida tropicalis & 7 & $4-8$ & $>64$ & $2-8$ & 64 to $>64$ & 64 to $>64$ \\
\hline Candida parapsilosis & 3 & $0.5-8$ & $>64$ & 1 to $>64$ & 64 to $>64$ & 1 to $>64$ \\
\hline Malassezia furfur & 2 & 1 & - & - & - & - \\
\hline \multicolumn{7}{|l|}{ Molds } \\
\hline Aspergillus fumigatus & 3 & $0.5-1$ & 64 to $>64$ & $1-2$ & $32-64$ & $>64$ \\
\hline Aspergillus niger & 3 & 1 & $>64$ & $1-4$ & $2-4$ & $1-64$ \\
\hline Aspergillus amsteloidami & 2 & $\leq 0.06-0.5$ & 64 to $>64$ & $0.13-1$ & $2-32$ & 8 \\
\hline Aspergillus repens & 2 & $1-16$ & $>64$ & $1-4$ & 4 & 8 to $>64$ \\
\hline Aspergillus ruber & 2 & $0.5-1$ & $>64$ & 1 & $>64$ & $>64$ \\
\hline Aspergillus candidus & 1 & 1 & $>64$ & 1 & 16 & 1 \\
\hline Aspergillus chevalieri & 1 & 4 & 64 & 1 & 16 & $>64$ \\
\hline Aspergillus ustus & 1 & 0.5 & $>64$ & 1 & 16 & 16 \\
\hline Penicillium commune & 1 & 0.5 & $>64$ & 1 & 16 & 8 \\
\hline \multicolumn{7}{|l|}{ Others } \\
\hline Scopulariopsis brevicaulis & 2 & 1 & $>64$ & 0.5 & 8 & 8 \\
\hline Geotrichum candidum & 1 & 8 & $>64$ & 2 & $>64$ & 64 \\
\hline Madurella mycetomatis & 1 & 0.25 & $>64$ & 1 & 8 & 1 \\
\hline
\end{tabular}

Inoculum size: $10^{4} \mathrm{CFU} / \mathrm{ml}$; culture and culturing conditions: dermatophytes $=$ Kimmig's liquid culture $\left(28^{\circ} \mathrm{C}, 5\right.$ days $)$; yeasts $=$ YNB liquid culture $\left(37^{\circ} \mathrm{C}, 3\right.$ days $)$; molds, others $=\mathrm{T} 3$ liquid culture $\left(28^{\circ} \mathrm{C}, 5\right.$ days $)$.

Abafungin exerts its fungicidal activity regardless of whether the pathogens in question are growing or in a resting state. The non-growing dermatophytes and yeastlike fungi tested to date were killed with drug concentrations $<16 \mathrm{mg} / \mathrm{l}$, and only in rare instances $32 \mathrm{mg} / \mathrm{l}$ were required. When tested against resting fungi, abafungin was superior to all the other comparator drugs used, including terbinafine and amorolfine (table 3; fig. 2, 3).
Studies on the time dependence of fungicidal activity of abafungin revealed that loss of viability was achieved in a concentration- and strain-dependent manner. Yeasts were killed between 1 and $48 \mathrm{~h}$, and dermatophytes and molds between 1 and 5 days after incubation. 
Table 2. Fungicidal activity of abafungin and comparator drugs against various pathogenic fungi (broth dilution assay)

\begin{tabular}{|c|c|c|c|c|c|c|}
\hline \multirow[t]{2}{*}{ Organism } & \multirow{2}{*}{$\begin{array}{l}\text { Strains } \\
\mathrm{n}\end{array}$} & \multicolumn{5}{|c|}{ MFC range, $\mu \mathrm{g} / \mathrm{ml}$} \\
\hline & & abafungin & bifonazole & clotrimazole & terbinafine & amorolfine \\
\hline \multicolumn{7}{|l|}{ Dermatophytes } \\
\hline Trichophyton mentagrophytes & 5 & $\leq 0.06-0.5$ & 32 & $1-8$ & $\leq 0.06$ & $0.13-2$ \\
\hline Trichophyton rubrum & 5 & $\leq 0.06-0.25$ & $4-32$ & $4-8$ & $\leq 0.06-0.13$ & $0.13-0.5$ \\
\hline Trichophyton equinum & 2 & $0.5-2$ & $16-32$ & $1-2$ & $\leq 0.06$ & 0.13 \\
\hline Trichophyton tonsurans & 4 & $0.25-0.5$ & $16-32$ & 8 & $\leq 0.06$ & $0.13-8$ \\
\hline Trichophyton ajelloi & 1 & $\leq 0.06$ & 8 & 1 & $\leq 0.06$ & 0.5 \\
\hline Trichophyton gallinae & 1 & 1 & 8 & 1 & $\leq 0.06$ & 2 \\
\hline Trichophyton schoenleinii & 1 & $\leq 0.06$ & 8 & 2 & 0.13 & 1 \\
\hline Trichophyton verrucosum & 2 & 0.13 & 32 & 8 & $\leq 0.06$ & 0.13 \\
\hline Trichophyton violaceum & 1 & 0.5 & 32 & 16 & $\leq 0.06$ & 2 \\
\hline Epidermophyton floccosum & 1 & 0.25 & 16 & 1 & $\leq 0.06$ & 0.13 \\
\hline Microsporum canis & 4 & $\leq 0.06-1$ & 8 to $>64$ & $1-16$ & $\leq 0.06$ & $1-8$ \\
\hline Microsporum gypseum & 2 & $\leq 0.06-2$ & 32 & 1 & $\leq 0.06$ & 0.13 \\
\hline Clinical isolates, not characterized & 14 & $\leq 0.06-2$ & 8 to $>64$ & $1-16$ & $\leq 0.06-0.25$ & $0.13-1$ \\
\hline \multicolumn{7}{|l|}{ Yeast } \\
\hline Candida albicans & 8 & $8-16$ & $>64$ & 2 to $>64$ & 32 to $>64$ & 4 to $>64$ \\
\hline Candida glabrata & 8 & $2-16$ & $>64$ & 4 to $>64$ & 4 to $>64$ & 4 to $>64$ \\
\hline Candida guilliermondii & 5 & $4-16$ & $>64$ & 1 to $>64$ & $>64$ & $>64$ \\
\hline Candida krusei & 5 & $2-8$ & $>64$ & $2-8$ & $>64$ & 4 to $>64$ \\
\hline Candida tropicalis & 7 & 16 & $>64$ & 8 to 64 & $>64$ & 64 to $>64$ \\
\hline Candida parapsilosis & 3 & 8 & $>64$ & 1 to $>64$ & $>64$ & $>64$ \\
\hline Malassezia furfur & 2 & 1 & - & - & - & - \\
\hline \multicolumn{7}{|l|}{ Molds } \\
\hline Aspergillus fumigatus & 3 & 4 & 64 to $>64$ & $>64$ & $>64$ & $>64$ \\
\hline Aspergillus niger & 3 & 4 & $>64$ & 64 to $>64$ & $2-4$ & $>64$ \\
\hline Aspergillus amsteloidami & 2 & 4 & 64 to $>64$ & $>64$ & $2-32$ & $>64$ \\
\hline Aspergillus repens & 2 & $4-32$ & $>64$ & $>64$ & 4 & $>64$ \\
\hline Aspergillus ruber & 2 & 4 & $>64$ & $>64$ & $>64$ & $>64$ \\
\hline Aspergillus candidus & 1 & 4 & $>64$ & $>64$ & 16 & $>64$ \\
\hline Aspergillus chevalieri & 1 & 16 & 64 & 64 & 16 & $>64$ \\
\hline Aspergillus ustus & 1 & 4 & $>64$ & $>64$ & 16 & $>64$ \\
\hline Penicillium commune & 1 & 4 & $>64$ & $>64$ & 16 & $>64$ \\
\hline \multicolumn{7}{|l|}{ Others } \\
\hline Scopulariopsis brevicaulis & 2 & 4 & $>64$ & $>64$ & 8 & $>64$ \\
\hline Geotrichum candidum & 1 & 16 & $>64$ & $>64$ & $>64$ & $>64$ \\
\hline Madurella mycetomatis & 1 & 4 & $>64$ & $>64$ & 8 & $>64$ \\
\hline
\end{tabular}

Inoculum size: $10^{4} \mathrm{CFU} / \mathrm{ml}$; culture and culturing conditions: dermatophytes $=$ Kimmig's liquid culture $\left(28^{\circ} \mathrm{C}, 5\right.$ days $)$; yeasts $=$ YNB liquid culture $\left(37^{\circ} \mathrm{C}, 3\right.$ days $)$; molds, others $=\mathrm{T} 3$ liquid culture $\left(28^{\circ} \mathrm{C}, 5\right.$ days $)$.

Effect of Culture Medium, $\mathrm{pH}$ and Inoculum Size on Activity

With C. albicans TIMM 0144 growing in YNB, slightly delayed activity was observed using $10 \mathrm{mg} / \mathrm{l}$ abafungin and immediate loss of viability $<1 \mathrm{~h}$ after addition of 40 $\mathrm{mg} / \mathrm{l}$.

If the concentration of free agent is reduced by strong binding to additives, higher drug concentrations are re- quired to reach inhibition. This was not only observed with proteins but also with agaropectin. When abafungin was tested in a Sabouraud dextrose agar dilution assay, significantly higher MICs (table 4) were obtained compared to MICs in liquid culture, in particular against yeast isolates (table 1). Agar consists of two polymers, the neutral agarose and agaropectin with sulfuric acid covalently linked to about every tenth galactopyranose sub- 


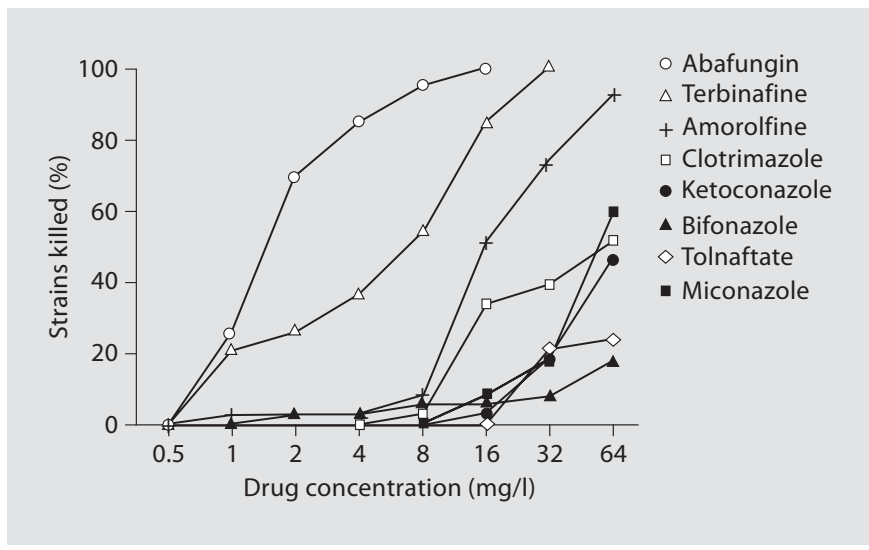

Fig. 2. Fungicidal activity of different antifungals against 39 clinical isolates of dermatophytes in demineralized water.

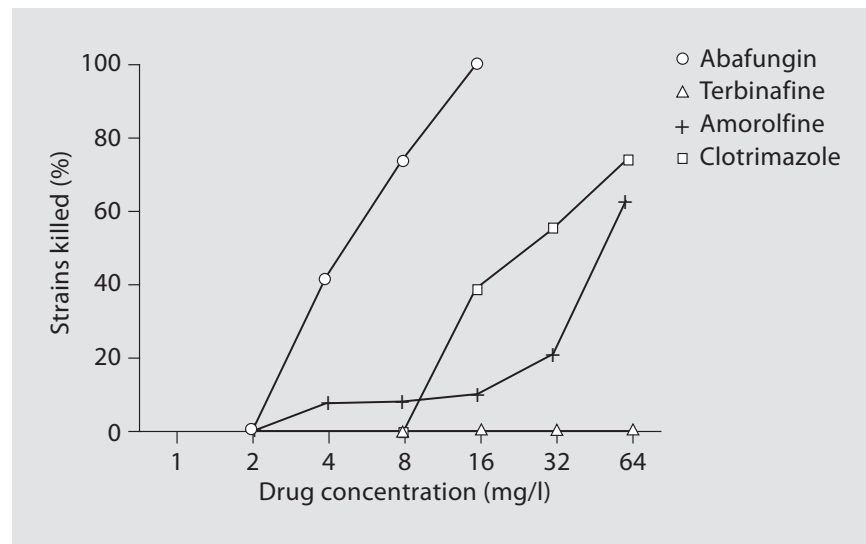

Fig. 3. Fungicidal activity of different antifungals against 39 clinical isolates of yeasts in physiological saline. MFC ( $99 \%$ reduction of $10^{4} \mathrm{CFU} / \mathrm{ml}$ ) was determined after 3 days of incubation at $37^{\circ} \mathrm{C}$.
Table 3. Fungicidal activity of abafungin and comparator drugs against resting cells

\begin{tabular}{llll}
\hline $\begin{array}{l}\text { Antifungal } \\
\text { agent }\end{array}$ & \multicolumn{2}{l}{ MFC range, $\mu \mathrm{g} / \mathrm{ml}$} & \\
\cline { 2 - 4 } & $\begin{array}{l}\text { dermatophytes } \\
\begin{array}{l}43 \text { isolates } \\
\text { in demineralized water }\end{array}\end{array}$ & $\begin{array}{l}\text { yeast } \\
38 \text { isolates } \\
\text { in saline }\end{array}$ & $\begin{array}{l}\text { molds } \\
20 \text { isolates } \\
\text { in saline }\end{array}$ \\
\hline $\begin{array}{l}\text { Abafungin } \\
\text { Amorolfine }\end{array}$ & $1-16$ & $4-16$ & $4-32$ \\
Bifonazole & 1 to $>64(85 \%)$ & 4 to $>64(63 \%)$ & $>64(0 \%)$ \\
Clotrimazole & 8 to $>64(18 \%)$ & $>64(0 \%)$ & not done \\
Terbinafine & 8 to $>64(51 \%)$ & $>64(74 \%)$ & 64 to $>64(5 \%)$ \\
$1-32$ & $>64(0 \%)$ & not done \\
\hline
\end{tabular}

Isolates killed at $64 \mathrm{mg} / \mathrm{l}$ are given in parentheses. The inoculum was $10^{4} \mathrm{CFU} / \mathrm{ml}$. Dermatophytes and molds were incubated at $28^{\circ} \mathrm{C}$ for 5 days, yeasts for 3 days at $37^{\circ} \mathrm{C}$. unit. In an agarose dilution assay, no reduction of drug activity was observed (table 5). If different batches of agarose were used with different degrees of sulfuric acid substitution, the activity of abafungin was strongly dependent upon the amount of sulfuric acid present (table 6).

The influence of inoculum size and $\mathrm{pH}$ on the MFC was studied by broth dilution assay. The strong fungicidal activity of abafungin in the chemically defined YNB glucose medium at $\mathrm{pH} 5$ was almost independent of the inoculum size (table 7). The solubility of the agent in saltcontaining protein-free liquid media is about $1 \mathrm{mg} / \mathrm{l}$ at neutral $\mathrm{pH}$. It increases to $10 \mathrm{mg} / \mathrm{l}$ in acidified solutions ( $\mathrm{pH}$ 5.0).

Abafungin exerts a fungicidal activity preferably in defined minimal media or slightly enriched liquid media at a $\mathrm{pH}$ range of 4.0-5.5. Almost no activity of abafungin against yeasts was observed in complex nutrient-rich media like Kimmig's medium at $\mathrm{pH} 6.0$ due to $\mathrm{pH}$ and protein binding of the drug. However, if the $\mathrm{pH}$ was adjusted to 5.0, the increased solubility was sufficient to allow fungicidal effects (table 8).

Minor decrease of activity was observed if the $\mathrm{pH}$ was lowered from 5.0 to 3.0. This indicates that the fungicidal activity of abafungin was not significantly dependent upon $\mathrm{pH}$ within this range.

\section{Mode of Action Studies}

Mode of action studies with abafungin started with the observation that this agent exerts its antifungal activity regardless of whether the pathogens in question are growing or rather in a resting state. One possible target for abafungin could therefore consist of the fungal cell 
Table 4. Antimicrobial activity of abafungin and comparator drugs against various pathogenic fungi (agar dilution test)

\begin{tabular}{|c|c|c|c|c|}
\hline \multirow[t]{2}{*}{ Organism } & \multirow{2}{*}{$\begin{array}{l}\text { Strains } \\
\mathrm{n}\end{array}$} & \multicolumn{3}{|c|}{ MFC range, $\mu \mathrm{g} / \mathrm{ml}$} \\
\hline & & abafungin & bifonazole & clotrimazole \\
\hline \multicolumn{5}{|l|}{ Dermatophytes } \\
\hline Trichophyton mentagrophytes & 7 & $0.08-0.63$ & $0.16-5$ & $0.08-1.25$ \\
\hline Trichophyton rubrum & 2 & 0.31 & $0.63-5$ & $0.08-0.63$ \\
\hline Trichophyton violaceum & 1 & 0.63 & 10 & 1.25 \\
\hline Microsporum audoinii & 1 & 0.63 & 10 & 0.63 \\
\hline Microsporum canis & 4 & $0.08-1.25$ & $1.25-10$ & $0.08-1.25$ \\
\hline Microsporum gypseum & 2 & $0.63-1.25$ & 10 & 0.63 \\
\hline Epidermophyton floccosum & 3 & $\leq 0.04-0.16$ & $\leq 0.04$ & $0.16-0.31$ \\
\hline \multicolumn{5}{|l|}{ Yeast } \\
\hline Candida albicans & 3 & $10-80$ & $20-40$ & $5-20$ \\
\hline Candida albicans var. stellatoidea & 1 & 10 & 40 & 2.5 \\
\hline Candida tropicalis & 2 & 40 & 80 & 10 \\
\hline Candida kefyr & 1 & 10 & 10 & 2.5 \\
\hline Candida parapsilosis & 1 & 20 & 40 & 1.25 \\
\hline Candida krusei & 1 & 5 & 20 & 1.25 \\
\hline Candida guilliermondii & 1 & 5 & 20 & 2.5 \\
\hline Candida glabrata & 2 & $10-80$ & $5-40$ & $0.63-10$ \\
\hline Cryptococcus neoformans & 3 & $20-80$ & $10-20$ & $2.5-5$ \\
\hline Cryptococcus laurentii & 1 & 5 & 1.25 & 0.16 \\
\hline Cryptococcus terreus & 1 & 0.31 & 0.63 & 5 \\
\hline Trichosporon cutaneum & 2 & $2.5-20$ & $0.31-5$ & $0.16-1.25$ \\
\hline Rhodotorula cutanea & 1 & 0.63 & 0.31 & 0.63 \\
\hline Malassezia furfur & 8 & $2.5-40$ & $2.5-20$ & $10-80$ \\
\hline Malassezia pachydermatitis & 11 & $0.63-10$ & $1.25-10$ & $10-80$ \\
\hline \multicolumn{5}{|l|}{ Molds } \\
\hline Aspergillus fumigatus & 3 & $1.25-2.5$ & 2.5 & 2.5 \\
\hline Aspergillus clavatus & 1 & 20 & 40 & 2.5 \\
\hline Aspergillus flavus & 1 & $>80$ & 20 & 2.5 \\
\hline Aspergillus nidulans & 2 & $2.5-5$ & 2.5 & $0.16-0.63$ \\
\hline Aspergillus niger & 1 & 10 & 2.5 & 5 \\
\hline Aspergillus terreus & 2 & 1.25 & $1.25-2.5$ & 2.5 \\
\hline Aspergillus versicolus & 1 & 5 & 10 & 5 \\
\hline Penicillium citrinum & 1 & 5 & 2.5 & 2.5 \\
\hline Penicillium commune & 1 & 10 & 2.5 & 2.5 \\
\hline Penicillium crustaceum & 1 & 5 & 1.25 & 1.25 \\
\hline \multicolumn{5}{|l|}{ Dematiaceous fungi } \\
\hline Fonsecaea pedrosoi & 2 & $0.63-1.25$ & $\leq 0.04$ & $0.31-2.5$ \\
\hline Fonsecaea compacta & 2 & 1.25 & $0.08-0.16$ & 5 \\
\hline Phialophora verrucosa & 2 & $5-10$ & 0.63 & 5 \\
\hline Exophiala dermatitidis & 2 & $5-10$ & $0.63-1.25$ & $5-10$ \\
\hline Exophiala werneckii & 2 & $5-10$ & $0.31-1.25$ & $1.25-2.5$ \\
\hline Cladosporium bantianum & 2 & 2.5 & 1.25 & 10 \\
\hline Cladosporium mansonii & 2 & 0.63 & $\leq 0.04-0.16$ & $0.63-1.25$ \\
\hline \multicolumn{5}{|l|}{ Dimorphic fungi } \\
\hline Sporothix schenckii & 3 & 1.25 & 20 & 20 \\
\hline Histoplasma capsulatum & 2 & $0.16-0.31$ & $0.31-0.63$ & 0.08 \\
\hline Paracoccidioides brasiliensis & 3 & $0.16-1.25$ & $\leq 0.04-5$ & $0.16-0.63$ \\
\hline Blastomyces dermatitis & 2 & $\leq 0.08-0.16$ & $\leq 0.04-2.5$ & $0.08-0.63$ \\
\hline Geotrichum candidum & 1 & $>80$ & 80 & 10 \\
\hline
\end{tabular}

Inoculum size $=10^{6} \mathrm{CFU} / \mathrm{ml}$. Culture and culturing conditions: dermatophytes $/$ dematiaceous fungi $=$ Sabouraud dextrose agar culture $\left(27^{\circ} \mathrm{C}, 7\right.$ days); yeast-like fungi $($ Malassezia $)=$ potato dextrose agar culture $\left(27^{\circ} \mathrm{C}, 5\right.$ days); dimorphic fungi $=$ Sabouraud dextrose agar culture $\left(27^{\circ} \mathrm{C}, 10\right.$ days). 
Fig. 4. Increase in conductivity by abafun$\mathrm{CFU} / \mathrm{ml}$ in distilled water. gin. Inoculum size of C. albicans $\mathrm{H} 12: 10^{8}$

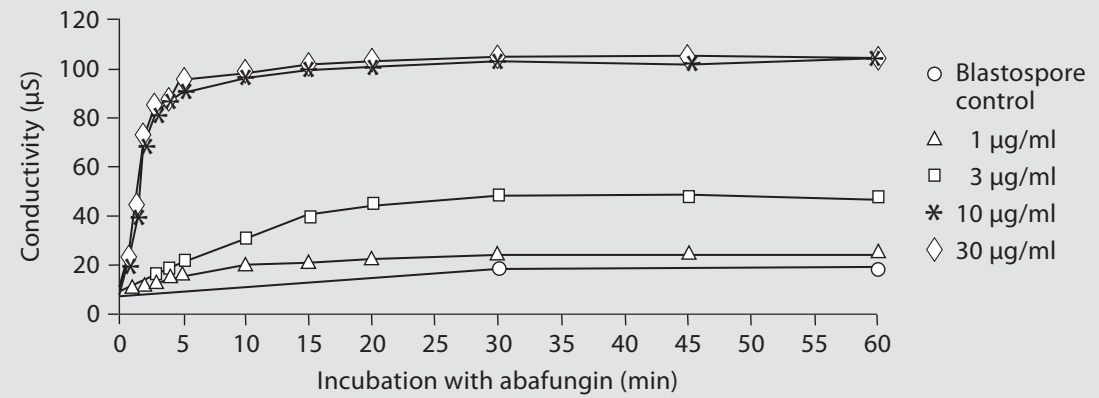

Table 5. Fungicidal activity of abafungin and comparator drugs against Candida spp. (agarose dilution test)

\begin{tabular}{lcc}
\hline Organism & $\begin{array}{l}\text { Strains } \\
\mathrm{n}\end{array}$ & $\begin{array}{l}\text { MFC-range, } \mu \mathrm{g} / \mathrm{ml} \\
\text { abafungin }\end{array}$ \\
\hline Yeasts & & \\
$\quad$ Candida albicans & 10 & $0.5-8$ \\
Candida tropicalis & 10 & $2-16$ \\
Candida krusei & 5 & $0.5-4$ \\
Candida glabrata & 10 & $1-4$ \\
\hline
\end{tabular}

Inoculum size $=10^{6}$ cells $/ \mathrm{ml}$. Culture and culturing conditions: yeasts $=$ Sabouraud dextrose agarose $\left(37^{\circ} \mathrm{C}, 4\right.$ days $)$; subculture on drug-free agar plates $\left(37^{\circ} \mathrm{C}, 14\right.$ days).

membrane. The impairment of the cell membrane function was tested by direct measurements of conductivity increase. Studies were carried out with C. albicans, and it was observed that abafungin, similar to polymers, caused a release of ions from cells within 2 min after addition of $10 \mathrm{mg} / \mathrm{l}$ or with higher concentrations. The ion release was measured as conductivity increase in the supernatant of resting cells (fig. 4). Further studies indicated that, within this short period, $\mathrm{K}^{+}$representing monovalent cations was released into the supernatant (fig. 5). Simultaneously, ATP leakage and ATP degradation were observed in resting cells. While total (intra- and extracellular) ATP decreased until about $7 \mathrm{~min}$ after drug addition, during the same time period extracellular ATP reached about $60 \%$ of its maximum level (fig. 6). Already after $5 \mathrm{~min}$, the number of CFU in the culture was reduced to $<0.1 \%$ (fig. 6). In growing cells immediately after drug addition, a short but significant increase in ATP synthesis was observed above control level followed by ATP degradation. Compared to resting cells, ATP leakage was reduced. The
Table 6. Effect of agar/agarose on the susceptibility of clinical isolates of C. albicans $(\mathrm{n}=25)$ to abafungin and bifonazole

\begin{tabular}{llcc}
\hline Agar/agarose & $\begin{array}{l}\text { Sulfated } \\
\text { ash }\end{array}$ & \multicolumn{2}{l}{ Geometric mean } \\
\cline { 3 - 4 } & & abafungin,$\mu \mathrm{g} / \mathrm{ml}$ \\
\hline Agarose A & 0.1 & 1.78 & bifonazole \\
Agarose B & 0.35 & 11.1 & 7.60 \\
Agarose C & 1.0 & $>80$ & 6.80 \\
Agar & $2-6$ & $>80$ & 5.80 \\
\hline
\end{tabular}

Medium $=$ casitone $0.9 \%$, glucose $2 \%$, yeast extract $1 \%$, $\mathrm{KH}_{2} \mathrm{PO}_{4} 0.1 \%, \mathrm{Na}_{2} \mathrm{HPO}_{4} 0.1 \%$, sodium citrate $1 \%$; medium $\mathrm{pH}=$ 6.4; test condition $=27^{\circ} \mathrm{C}$, 4 days; inoculum size $=10^{6} \mathrm{cell} / \mathrm{s} / \mathrm{ml}$.

${ }^{1}$ Residue on combustion.

Table 7. Dependence of the fungicidal activity of abafungin on the inoculum size of C. albicans $\mathrm{H} 12$

\begin{tabular}{lc}
\hline Inoculum, CFU/ml & $\mathrm{MFC}, \mu \mathrm{g} / \mathrm{ml}$ \\
\hline $10^{2}$ & 4 \\
$10^{3}$ & $4-8$ \\
$10^{4}$ & 8 \\
$10^{5}$ & $8-16$ \\
$10^{6}$ & $16-32$ \\
\hline
\end{tabular}

MFC (99.9\% reduction in CFU) after 2 days of incubation at $37^{\circ} \mathrm{C}$ in yeast nitrogen. Base with $1 \%$ glucose.

loss of viability occurred later in growing cells [32] (fig. 7).

The observed effects of abafungin indicate that this new agent has probably at least two modes of action in yeast cells. At a low concentration $\left(10^{-7} \mathrm{M}\right)$, a specific inhibition of ergosterol biosynthesis was found. At higher 
Table 8. MFC's of abafungin at different $\mathrm{pH}$ values

\begin{tabular}{|c|c|c|c|c|c|c|c|c|}
\hline \multicolumn{2}{|c|}{ Clinical insolates (n) } & \multicolumn{7}{|c|}{$\begin{array}{l}\text { Cumulative percentage of strains killed ( } 99 \% \text { reduction of } 1 \cdot 10^{4} \mathrm{CFU} / \mathrm{ml} \text { after } \\
3 \text { days of incubation in Kimmig at } 37^{\circ} \mathrm{C} \text { ) }\end{array}$} \\
\hline & & 2 & 4 & 8 & 16 & 32 & 64 & $\mathrm{pH}$ \\
\hline C. albicans & (10) & 10 & 10 & 30 & 100 & 90 & 100 & 3.0 \\
\hline C. glabrata & (10) & & 30 & 40 & & & & \\
\hline C. tropicalis & (10) & & 30 & 100 & & & & \\
\hline C. albicans & $(10)$ & & & 20 & 90 & 100 & & 4.0 \\
\hline C. glabrata & (10) & & 20 & 40 & & 70 & 100 & \\
\hline C. tropicalis & $(10)$ & & 10 & 50 & 100 & & & \\
\hline C. albicans & $(10)$ & 10 & 10 & 60 & 100 & & & 5.0 \\
\hline C. glabrata & (10) & & 30 & 40 & 80 & 100 & & \\
\hline C. tropicalis & $(10)$ & & 10 & 60 & 90 & 100 & & \\
\hline C. albicans & $(10)$ & & 10 & & & 20 & & 6.0 \\
\hline C. glabrata & (10) & & & & & & & \\
\hline C. tropicalis & (10) & & & & & & & \\
\hline
\end{tabular}

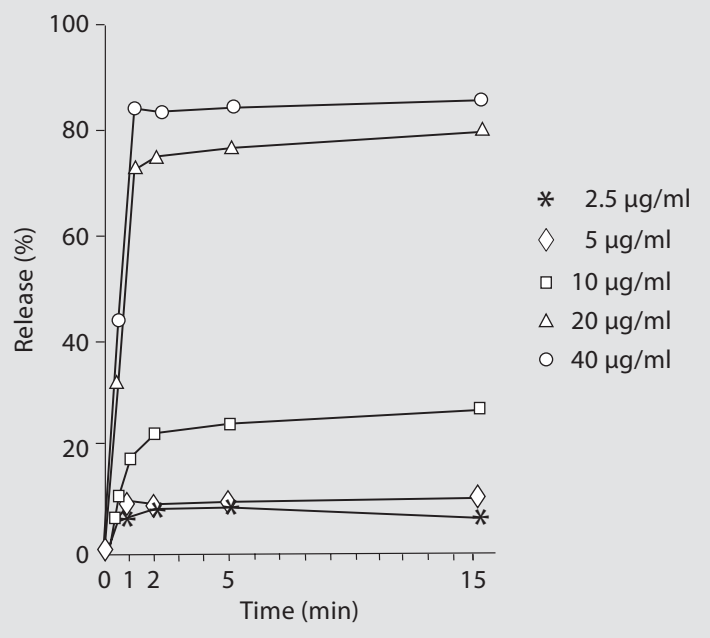

Fig. 5. Effect of abafungin on the release of potassium from $C$. albicans TIMM 0144.

concentrations $\left(10^{-4} \mathrm{M}\right)$, the drug caused lethal direct membrane damage. Irrespective of the potential physiological relevance of these concentrations, we felt tempted to address the question of whether these membrane effects were induced by a specific interaction with membrane components. We recorded difference spectra with various lipids and phospholipids. No interaction of abafungin was seen with the phospholipids, phosphatidylcholine, phosphatidylethanolamine and cardiolipin, very weak signals with phosphatidylinositol and strong interaction with phosphatidylserine (fig. 8). Using similar experiments with cholesterol, ergosterol and sitosterol, spectra did not differ.

\section{Effect on Ergosterol Biosynthesis}

During initial investigations of the fungicidal mode of action of abafungin against phythopathogenic fungi, an accumulation of lanosterol was found by gas chromatography-mass spectroscopy analysis of the sterols [Berg, unpubl. results]. This is indicative of an inhibition of the enzyme sterol-C-24 methyltransferase which transfers a methyl group to the C-24 position of the side chain of lanosterol. Sterol C-24 methylation is a cytochrome $\mathrm{P}_{450^{-}}$ independent process, requiring S-adenosyl-L-methionine as the methyl donor. Therefore, we examined the incorporation rate of $\mathrm{L}-\left[\right.$ methyl- $\left.{ }^{14} \mathrm{C}\right]$-methionine into sterol in the presence of abafungin. Abafungin inhibited incorporation of radioactivity into sterol at $0.01 \mu \mathrm{g} / \mathrm{ml}$ or higher (table 9). The inhibitory effect was noted at much lower concentrations than for sinefungin, the S-adenosyl-L-methionine antagonist of choice. This result shows that abafungin inhibits transmethylation of the sterol side chain at low concentrations $(0.01-10 \mu \mathrm{g} / \mathrm{ml})$. 
Fig. 6. ATP leakage and degradation of $C$. albicans $\mathrm{H} 12$ induced by abafungin in bidistilled water.

Fig. 7. ATP in growing cells of C. albicans $\mathrm{H} 12$ treated with abafungin in YMM ( $\mathrm{pH}$ 5.0).

Fig. 8. Difference spectra of abafungin with phospholipids. In each case, the baseline (bl) and the difference spectrum from $190 \mathrm{~nm}$ (left side) to $350 \mathrm{~nm}$ is shown. The concentrations of all phospholipids and of abafungin were $10^{-4} \mathrm{M}$, except for phosphatidylserine + abafungin (each $\left.5 \times 10^{-5} \mathrm{M}\right)$.

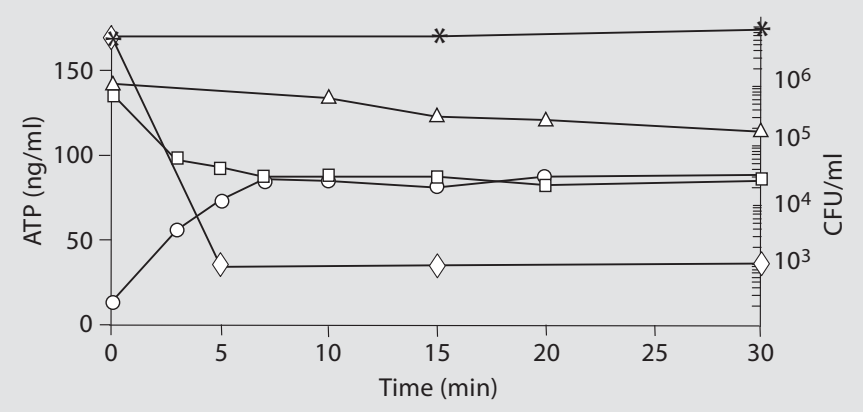

- Extracellular ATP

$\triangle$ Total ATP

$\square$ Total ATP

* CFU control

$\checkmark$ CFU $30 \mathrm{mg} / \mathrm{l}$

abafungin

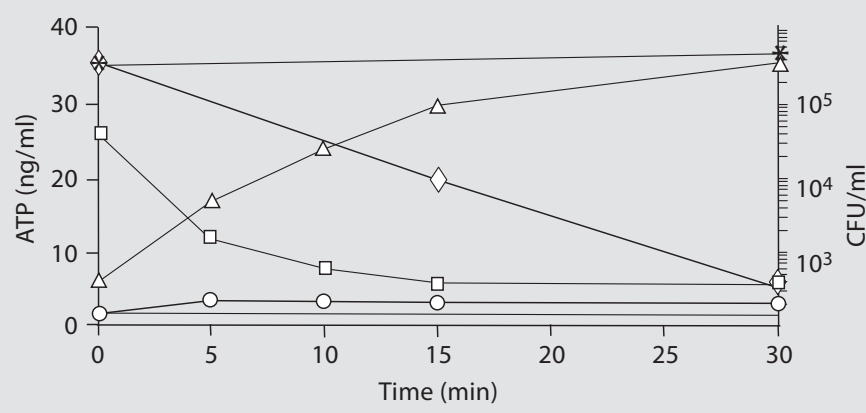

O ExtracellularATP

$\triangle$ Total ATP

$\square$ Total ATP

* CFU control

$\checkmark$ CFU $30 \mathrm{mg} / \mathrm{l}$ abafungin

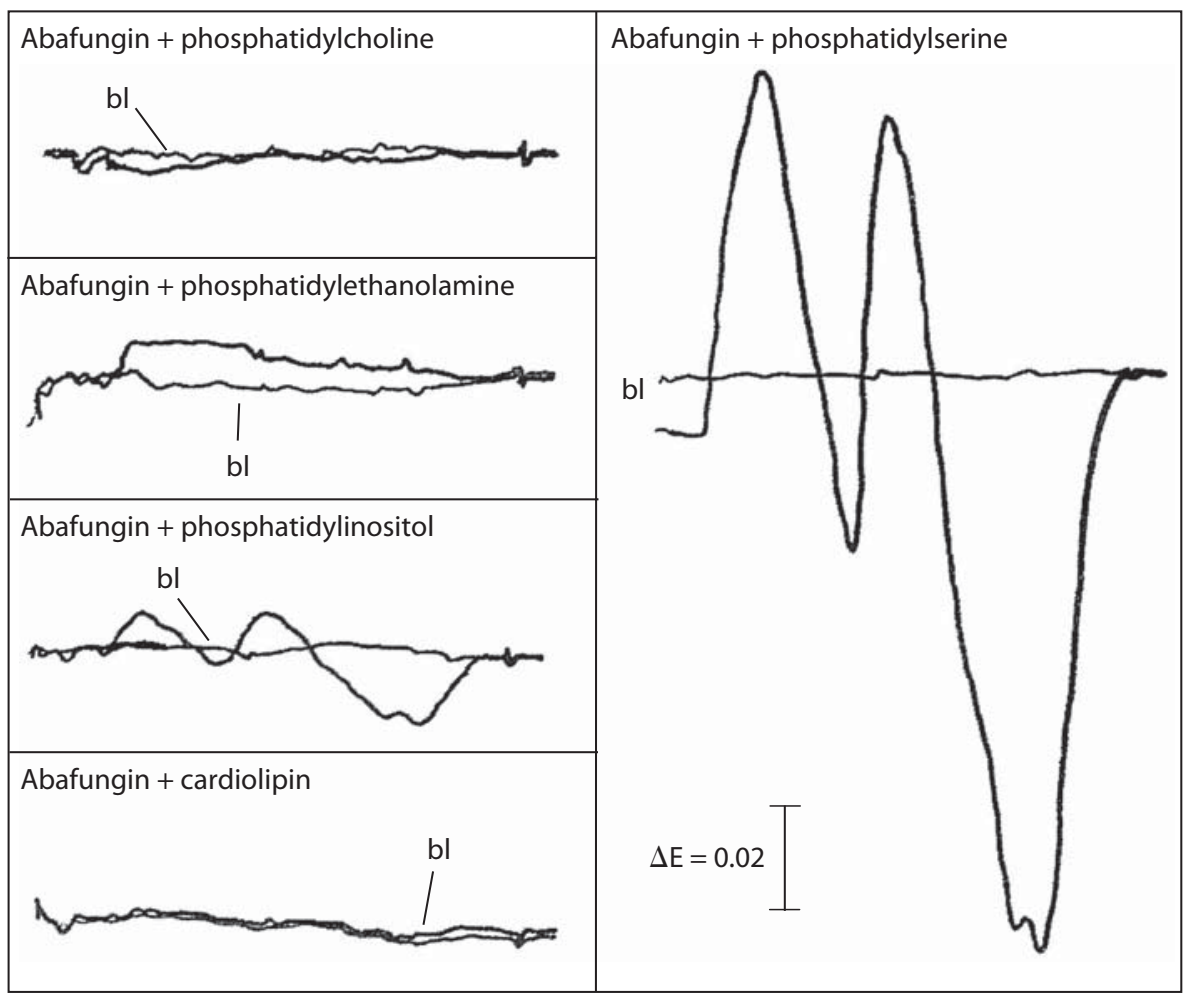


Fig. 9. Dual mode of action of abafungin by inhibition of the ergosterol biosynthesis and direct impairment of the cell membrane. SAM = S-adenosyl-L-methionine; SMT $=$ sterol-C-24 methyltransferase.

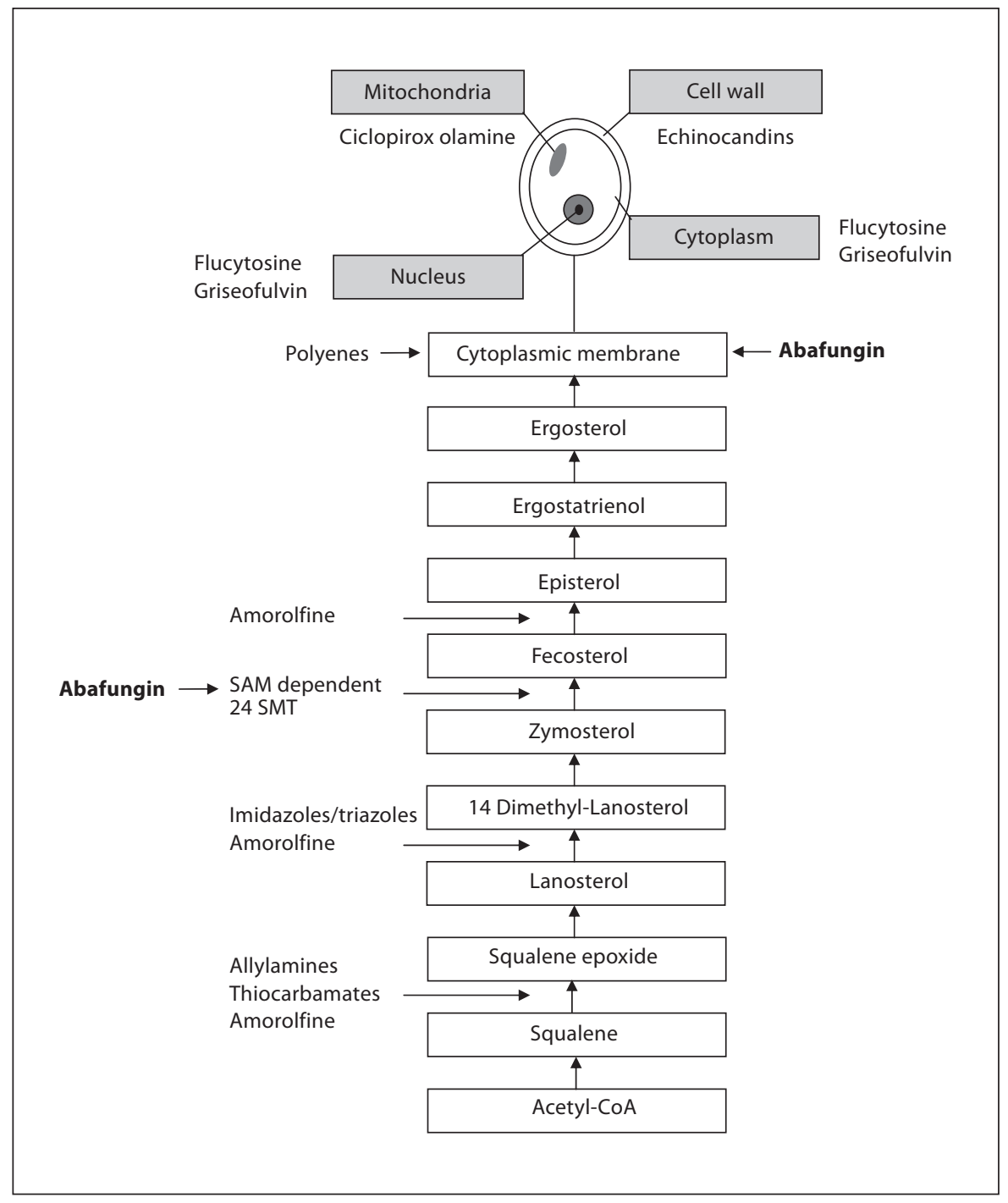

Table 9. Effect of $3 \mathrm{~h}$ treatment with abafungin and sinefungin on sterol composition of C. albicans

\begin{tabular}{lcl}
\hline Substance & $\begin{array}{l}\text { Concentration } \\
\mu \mathrm{g} / \mathrm{ml}\end{array}$ & $\begin{array}{l}\text { Incorporation rate } \\
\% \text { of control }\end{array}$ \\
\hline Abafungin & 0.001 & 92.5 \\
& 0.01 & 49.5 \\
& 0.1 & $<2.8$ \\
& 1 & $<0.1$ \\
Sinefungin & 10 & $<0.1$ \\
& 1 & 82.4 \\
& 10 & 29.6 \\
\hline
\end{tabular}

\section{Discussion}

Arylguanidines are a new class of antifungals distinguished by a broad primary antifungal activity against dermatophytes, yeast-like fungi and molds. In contrast to conventional antifungals of the azole type, they do not bind to cytochrome $\mathrm{P}_{450}$. Berg et al. [33] have shown that abafungin is a potent inhibitor of ergosterol biosynthesis in C. albicans at $0.01-1 \mathrm{mg} / \mathrm{l}$. Unlike conventional azoles, abafungin inhibits specifically the transmethylation of the sterol side chain. The enzyme involved in this reaction is the sterol-C-24 methyltransferase (fig. 9). Ryder [34] discussed in an early article the same mode of action for the allylamine antimycotic naftifine. In a publication 1 year later, he stated that the only target of 
the allylamines is the block of squalene epoxidation [26].

A partial growth inhibition of C. albicans was observed at a drug concentration $\geq 0.1 \mathrm{mg} / \mathrm{l}$. Fungicidal effects required $10-30 \mathrm{mg} / \mathrm{l}$ of abafungin. In this concentration range, membrane functions were impaired shortly after drug addition. In a culture of resting cells, a rapid leakage of potassium and ATP was observed similar to polyenes. Conductivity increased within 1-5 min after drug addition corresponding to extracellular potassium and ATP. Simultaneously, the cells degraded ATP to restore the membrane functions. About $7 \mathrm{~min}$ after abafungin addition, ATP depletion of the cells could be observed. At this time point, all remaining ATP $(\sim 60 \%)$ was accumulated extracellularly. Already after $5 \mathrm{~min}$, the number of CFU of the culture was reduced $<0.1 \%$ presumably as a consequence of breakdown of the energy metabolism. In growing cells of C. albicans, a short significant increase in ATP synthesis was observed above control level followed by ATP degradation. Compared to resting cells, a comparable loss of viability was reached later, at about $30 \mathrm{~min}$, presumably because membrane repair mechanisms were more effective in growing cells. This assumption is supported by the fact that ATP leakage was markedly reduced in growing cells, indicating that abafungin has a membrane-damaging effect analogous to the one found with dodecylguanidine (dodine) and sertaconazole, for example [35].

Further investigations were concerned with the question of whether the observed membrane-damaging effects of abafungin are related to a specific interaction with membrane components like lipids, and phospholipids in particular. Specific interactions of different compounds can be studied by recording UV difference spectra [36]. Interestingly, a significant spectrum of abafungin was obtained only with the phospholipid phosphatidylserine but not with phosphatidylcholine, phosphatidylethanolamine, phosphatidylinositol, cardiolipin and sterols like ergosterol, cholesterol and sitosterol. This indicates a specific interaction of abafungin with this membrane component.

Polyene antifungals like amphotericin B and nystatin are known to act by complexing sterols, which results in a lethal effect by forming transmembrane pores [37]. The interaction between amphotericin B and ergosterol seems to be more favorable for pore formation than that between amphotericin B and cholesterol [38]. Cellular components like potassium and ATP are found to leak out through these pores. Since similar leakage effects can be seen in abafungin-treated C. albicans cultures, it is as- sumed that a specific interaction of this new compound with phosphatidylserine leads to the observed membrane leakage and to the loss of the capacity to form colonies. The leakage of essential cell components becomes a lethal event only if the cells are unable to compensate for the membrane damage. Iwatani et al. [39] have demonstrated that the benzylamine butenafine induces the release of phosphorylated cellular components from C. albicans cells at $12.5 \mathrm{mg} / \mathrm{l}$. They claim a fungicidal activity at 50 $\mathrm{mg} / \mathrm{l}$. However, according to their own data, using 100 $\mathrm{mg} / \mathrm{l}$ butenafine, a reduction in the initial cell count of $C$. albicans of only one order of magnitude occurred within $48 \mathrm{~h}$. With abafungin we have demonstrated fungicidal activity against growing and resting cells with a reduction in the initial cell count of at least two or three orders of magnitude within $<1 \mathrm{~h}$ at the concentration which induces leakage of cellular components. Abafungin is a protonized alkaline agent which preferably binds to polymers like acid proteins and agaropectin, a polymer found in agar. This binding leads to a reduced concentration of free agent and as a consequence to reduced drug availability.

In polymer-free media, the activity of abafungin is mainly limited by its solubility. At neutral $\mathrm{pH}$, about $1 \mathrm{mg} / \mathrm{l} \mathrm{can}$ be dissolved. At pH 5.0, the solubility reaches about $10 \mathrm{mg} / \mathrm{l}$. All fungal isolates tested to date $(>300)$ were sensitive to abafungin at this slightly acidic $\mathrm{pH}$. Using Kimmig's medium it was demonstrated that only $10 \%$ of the clinical yeast isolates were sensitive to the drug at $\mathrm{pH} 6$, while all isolates responded at $\mathrm{pH} 5$.

It has long been known that some azoles can exert fungicidal activity at high concentrations by the induction of direct membrane damage [40]. In its broad antifungal activity against metabolizing and resting fungi, abafungin is apparently superior to the other antifungals tested. When tested against resting dermatophytes, it is even more active than terbinafine in this respect.

The experiments described above indicate that abafungin has at least two mechanisms of action in Candida cells: At concentrations of $10^{-7} \mathrm{M}$, it causes a dose-dependent specific inhibition of ergosterol biosynthesis. In the range of $10-40 \mu \mathrm{g} / \mathrm{ml}\left(10^{-4} \mathrm{M}\right)$, the agent induces release of potassium and ATP from yeast cells. The impairment of the cell membrane correlates with loss of viability. In the same concentration range where fungicidal activity was observed $\left(5 \times 10^{-5}\right.$ to $\left.10^{-4} \mathrm{M}\right)$, a significant interaction of abafungin with the phospholipid phosphatidylserine but not with other phospholipids or sterols could be recorded. 
Concerning direct impairment of the cell membrane, polyene antimycotics like amphotericin B and nystatin are known to act by binding to sterol, especially to ergosterol, which then leads to their lethal effect by forming transmembrane pores [38]. Cellular components like potassium ions and ATP then leak out through these pores. Moreover, some azoles exert fungicidal activity at high concentrations by the induction of direct impairment of the cell membrane, too [39-41].

In order to assess the clinical potential of abafungin further, in vitro data must be confirmed by data on in vivo antifungal activities in experimentally infected animals, and on the pharmacokinetics of the drug in animals and humans.

\section{Conclusion}

The above-described experiments and their results regarding abafungin, with relatively high and broad-spectrum antifungal activity, indicate that it might be a promising and useful additional agent in the therapeutic armamentarium for the topical treatment of fungal skin disease.

\section{Acknowledgment}

We thank the late Prof. Dr. K. Schaller for various, most valuable contributions to this paper. The authors are grateful to Dr. A. Polak for critical review of the manuscript.

\section{References}

1 Vanden Bossche H, Dromer F, Improvisi I, Lozano-Chiu M, Rex JH, Sanglard D: Antifungal drug resistance in pathogenic fungi. Med Mycol 1998;36(suppl 1):119-128.

2 Shao PL, Huang LM, Hsueh PR: Recent advances and challenges in the treatment of invasive fungal infections. Int $J$ Antimicrob Agents 2007;30:487-495.

3 Anderson JB: Evolution of antifungal-drug resistance: mechanisms and pathogen fitness. Nat Rev Microbiol 2005;3:547-556.

$\checkmark 4$ de Pauw BE, Meunier F: The challenge of invasive fungal infection. Chemotherapy 1999; 45(suppl 1):1-14.

5 Zhang AY, Camp WL, Elewski BE: Advances in topical and systemic antifungals. Dermatol Clin 2007;25:165-183, vi.

-6 Gupta AK, Tomas E: New antifungal agents. Dermatol Clin 2003;21:565-576.

7 Ghannoum MA, Rice LB: Antifungal agents: mode of action, mechanisms of resistance, and correlation of these mechanisms with bacterial resistance. Clin Microbiol Rev 1999;12:501-517.

-8 Bastert J, Schaller M, Korting HC, Evans EG: Current and future approaches to antimycotic treatment in the era of resistant fungi and immunocompromised hosts. Int J Antimicrob Agents 2001;17:81-91

-9 Francois IE, Aerts AM, Cammue BP, Thevissen K: Currently used antimycotics: spectrum, mode of action and resistance occurrence. Curr Drug Targets 2005;6:895-907.

10 Polak A: Mode of action of morpholine derivatives. Ann NY Acad Sci 1988;544:221228.

11 Bohme A, Karthaus M: Systemic fungal infections in patients with hematologic malignancies: indications and limitations of the antifungal armamentarium. Chemotherapy 1999;45:315-324.
12 Lupetti A, Danesi R, Campa M, Del Tacca M, Kelly S: Molecular basis of resistance to azole antifungals. Trends Mol Med 2002;8:76-81.

13 Gupta AK, Shear NH: Terbinafine: an update. J Am Acad Dermatol 1997;37:979988.

14 Korting HC, Schäfer-Korting M: Is tinea unguium still widely incurable? A review three decades after the introduction of griseofulvin. Arch Dermatol 1992;128:243-248.

15 Edlind TD, Katiyar SK: The echinocandin 'target' identified by cross-linking is a homolog of Pill and Lsp1, sphingolipid-dependent regulators of cell wall integrity signaling. Antimicrob Agents Chemother 2004;48: 4491.

-16 Aperis G, Mylonakis E: Newer triazole antifungal agents: pharmacology, spectrum, clinical efficacy and limitations. Expert Opin Investig Drugs 2006;15:579-602.

17 Shigematsu ML, Uno J, Arai T: Effect of ketoconazole on isolated mitochondria from Candida albicans. Antimicrob Agents Chemother 1982;21:919-924.

18 Sheehan DJ, Hitchcock CA, Sibley CM: Current and emerging azole antifungal agents. Clin Microbiol Rev 1999;12:40-79.

19 Leem SH, Park JE, Kim IS, Chae JY, Sugino A, Sunwoo Y: The possible mechanism of action of ciclopirox olamine in the yeast Saccharomyces cerevisiae. Mol Cells 2003;15: 55-61.

20 Niewerth M, Kunze D, Seibold M, Schaller M, Korting HC, Hube B: Ciclopirox olamine treatment affects the expression pattern of Candida albicans genes encoding virulence factors, iron metabolism proteins, and drug resistance factors. Antimicrob Agents Chemother 2003;47:1805-1817.
Sigle HC, Thewes S, Niewerth M, Korting HC, Schäfer-Korting M, Hube B: Oxygen accessibility and iron levels are critical factors for the antifungal action of ciclopirox against Candida albicans. J Antimicrob Chemother 2005;55:663-673.

22 Polak A: Preclinical data and mode of action of amorolfine. Dermatology 1992;184(suppl 1):3-7.

23 Haria M, Bryson HM: Amorolfine. A review of its pharmacological properties and therapeutic potential in the treatment of onychomycosis and other superficial fungal infections. Drugs 1995;49:103-120.

24 Urbina JA, Cohen BE, Perozo E, Cornivelli L: Spin-labeled amphotericin B: synthesis, characterization, biological and spectroscopic properties. Biochim Biophys Acta 1987;897:467-473.

25 Polak A, Scholer HJ: Fungistatic activity, uptake and incorporation of 5-fluorocytosine in Candida albicans, as influenced by pyrimidines and purines. II. Studies on distribution and incorporation. Pathol Microbiol (Basel) 1973;39:334-337.

26 Ryder NS, Frank I, Dupont MC: Ergosterol biosynthesis inhibition by the thiocarbamate antifungal agents tolnaftate and tolciclate. Antimicrob Agents Chemother 1986; 29:858-860.

-27 Kanafani ZA, Perfect JR: Antimicrobial resistance: resistance to antifungal agents: mechanisms and clinical impact. Clin Infect Dis 2008;46:120-128.

28 White TC, Marr KA, Bowden RA: Clinical, cellular, and molecular factors that contribute to antifungal drug resistance. Clin Microbiol Rev 1998;11:382-402.

29 Barker KS, Rogers PD: Recent insights into the mechanisms of antifungal resistance. Curr Infect Dis Rep 2006;8:449-456. 
30 Lundin A, Richardsson A, Thore A: Continuous monitoring of ATP-converting reactions by purified firefly luciferase. Anal Biochem 1976;75:611-620.

-31 Epand RM, Jones AJ, Sayer B: Molecular interactions in the model lipoprotein complex formed between glucagon and dimyristoylglycerophosphocholine. Biochemistry 1977; 16:4360-4368.

32 Schaller K, Itayama H, Tiemann R, Uchida K, Yamaguchi H: XII. Congress of the International Society for Human and Animal Mycology (ISHAM). Adelaide, South Australia, 1994, P7.3.

33 Berg D, Ytayama H, Schaller K, Tiemann R, Uchida K, Yamaguchi H, Zywitz A: XII. Congress of the International Society for Human and Animal Mycology (ISHAM). Adelaide, South Australia, 1994, PO2.52, D97.
\$4 Ryder NS: Effect of allylamine antimycotic agents on fungal sterol biosynthesis measured by sterol side-chain methylation. J Gen Microbiol 1985;131:1595-1602.

35 Agut J, Palacin C, Salgado J, Casas E, Sacris$\tan$ A, Ortiz JA: Direct membrane-damaging effect of sertaconazole on Candida albicans as a mechanism of its fungicidal activity. Arzneimittelforschung 1992;42:721-724.

36 Bell JE, Hall C: UV and visible absorbance spectroscopy; in Ellis JE (ed): Spectroscopy in Biochemistry. (Boca Raton, CRC Press, 1981.

37 Mishra P, Bolard J, Prasad R: Emerging role of lipids of Candida albicans, a pathogenic dimorphic yeast. Biochim Biophys Acta 1992;1127:1-14.
38 Ramos H, Attias de Murciano A, Cohen BE, Bolard J: The polyene antibiotic amphotericin $\mathrm{B}$ acts as a $\mathrm{Ca}^{2+}$ ionophore in sterol-containing liposomes. Biochim Biophys Acta 1989;982:303-306.

39 Iwatani W, Arika T, Yamaguchi H: Two mechanisms of butenafine action in Candida albicans. Antimicrob Agents Chemother 1993;37:785-788.

40 Sud IJ, Feingold DS: Heterogeneity of action of mechanisms among antimycotic imidazoles. Antimicrob Agents Chemother 1981; 20:71-74.

41 Ansehn S, Nilsson L: Direct membranedamaging effect of ketoconazole and tioconazole on Candida albicans demonstrated by bioluminescent assay of ATP. Antimicrob Agents Chemother 1984;26:22-25. 